\title{
Barcode DNA Tumbuhan Pangi (Pangium edule R.) Berdasarkan Gen matK
}

\author{
Irmi Bangola, Lidya Irma Momuata, Maureen Kumaunanga* \\ aJurusan Kimia, FMIPA, Unsrat, Manado
}

\begin{tabular}{l}
\hline K A T A K U N C I \\
\hline Pangium edule \\
gen matK \\
Barcode DNA \\
PCR \\
Elektroforesis
\end{tabular}

\begin{abstract}
A B S T R A K
DNA barcoding merupakan suatu teknik yang digunakan untuk mempercepat dan mempermudah proses identifikasi organisme dengan menggunakan potongan gen tertentu. Penelitian ini bertujuan untuk menentukan sekuens DNA barcode tumbuhan pangi berdasarkan gen standar matK dan membandingkannya dengan spesies yang berkerabat dekat di GenBank. DNA total daun pangi diisolasi menggunakan Innuprep plant DNA kit dan berhasil diamplifikasi dengan proses Polymerase Chain Reaction (PCR) menggunakan primer berdasarkan gen matK. Hasil sekuensing fragmen DNA yang menunjukkan panjang 720 bp yang teramplifikasi oleh primer forward dan 780 bp untuk yang teramplifikasi oleh primer reverse. Hasil analisis BLASTn menunjukkan tingkat kemiripan tumbuhan pangi sangat tinggi dengan Trichadenia zeylanical, yaitu 99\%, dan diikuti spesies lainnya (Kiggelaria africanal, 98\%; Guthriea capensis, 96\%; Acharia tragodes, 92\%; Erythrospermum phytolaccoides, 92\%; Hydnocarpus sp. Chase 1301, 90\%; Carpotroche longifolia, 89\%; Moultonianthus leembruggianus, $89 \%$ dan Pimelodendron zoanthogyne, 88\%). Analisis komposisi asam amino menunjukkan bahwa matk Pangium edule dan kesembilan spesies tumbuhan lainnya bersifat hidrofobik.
\end{abstract}

K E Y W O R D S

Pangium edule

matK gene

DNA barcode

PCR

Elektrophoresis

\section{A B S T R A C T}

DNA barcoding is a technical used to accelerate and simplify the process identification of organism with by using a snipping of specific genes. This study aimed to determine the DNA sequences of plant barcoding standard pangi based gene matK and compare with closely related species in GenBank. Total DNA was isolated using Innuprep pangi leaf plant DNA kit and successfully amplified by the Polymerase Chain Reaction (PCR) using primers based on the gene matK. The results of sequencing long DNA fragments showed7 20 bp are amplified by the forward primer and 780 bp were amplified by the primer for reverse. Blast analysis of the results showed very extremely high the plant pangi degree of similarity with Trichadenia zeylanical, namely99\%, and followed by other species (Kiggelaria africanal, 98\%; Guthriea capensis, 96\%; Acharia tragodes, 92\%; Erythrospermum phytolaccoides, 92\%; Hydnocarpus sp. Chase 1301, 90\%; Carpotroche longifolia, 89\%; Moultonianthus leembruggianus, 89\% dan Pimelodendron zoanthogyne, 88\%). Analysis of aminoacid composition showed that matK Pangium edule and nine other plant species are hydrophobic. 


\section{Pendahuluan}

Indonesia memiliki sumber daya alam hayati yang beranekaragam dan menghasilkan berbagai manfaat misalnya sebagai sumber pangan, insektisida dan obat-obatan. Pangi (Pangium edule Reinw) merupakan jenis tanaman beracun yang mengandung asam sianida, dapat digunakan sebagai insektisida, bahan pengawet serta dapat pula digunakan sebagai obat-obatan (Yuningsih et al., 2004). Di Sulawesi Utara daun pangi banyak dimanfaatkan oleh masyarakat sebagai sayuran bahkan dipercaya memiliki khasiat sebagai obat cacing kremi, sedangkan getah daunnya digunakan sebagai antiseptik dan desinfektan untuk membersihkan luka luar (Heriyanto dan Subiandono, 2008).

Basuni (1986) mengemukakan bahwa pang merupakan salah satu jenis tumbuhan yang sudah tersebar luas di wilayah Indonesia dan memiliki potensi cukup tinggi bagi masyarakat. Sehingga perlu dilakukan pendataan terhadap keragaman jenis tumbuhan pangi di Indonesia (Sulawesi Utara), sebelum terjadi kepunahan yaitu menggunakan metode Deoxyribose Nucleic Acid (DNA)barcoding. DNA barcoding merupakan salah satu teknik yang digunakan untuk mempercepat dan mempermudah proses identifikasi organisme dengan menggunakan potongan gen tertentu (Rimbawanto et al., 2012).

DNA barcoding dapat digunakan oleh ahli taksonomi dengan cepat dan relatif murah untuk mengidentifikasi spesies yang sulit dilakukan secara morfologi. Identifikasi dan mempertahankan keanekaragaman genetik suatu populasi sangat penting dalam suatu konservasi (Rimbawanto et al., 2012). Metode DNA barcoding ini diawali dengan tahap isolasi DNA total, dilanjutkan dengan tahap amplifikasi gen standar ribulosa-1,5-bifosfat karboksilase (rbcL) atau maturase $\mathrm{K}$ (matK) menggunakan Polymerase Chain Reaction (PCR) dan tahap sekuensing untuk mengidentifikasi sekuens DNA barcode pada tumbuhan. Gen standar ini digunakan untuk mempelajari keanekaragaman genetik tumbuhan berdasarkan sekuens DNA-nya. Perbedaannya, gen matK lebih sulit diamplifikasi tetapi memberikan resolusi yang lebih tinggi dalam membandingkan spesies tumbuhan, sedangkan gen $r b c L$ lebih mudah diamplifikasi, akan tetapi resolusinya rendah untuk dapat membedakan beberapa spesies yang berkerabat dekat. Konfirmasi keberhasilan amplifikasi fragmen gen dilakukan dengan visualisasi melalui elektroforesis. Fragmen gen yang berhasil diamplifikasi akan dianalisis untuk sekuensing DNA (Hollingsworth et al., 2011).

Berdasarkan tinjauan tersebut maka dilakukan penelitian yang bertujuan untuk mengisolasi dan menentukan DNA barcode tumbuhan pangi (Pangium edule R.) berdasarkan gen matK.

\section{Metode}

\subsection{Material}

Alat-alat yang digunakan dalam penelitian ini, adalah tabung mikro (Eppendorf) $1.5 \mathrm{~mL}$, tabung PCR $50 \mu \mathrm{L}$, gelas kimia, hot plate, mikrosentrifus, inkubator, kolom miniprep, termoblok, mesin PCR (Biometra T-personal, Jerman), 1 set alat elektroforesis, mikropipet, sarung tangan, kamera digital, freezer, spektrofotometer UV-Vis dan UVtransiluminator. Bahan-bahan yang digunakan dalam penelitian ini adalah daun pangi (diperoleh dari daerah Bolaang Mongondow di Tudu Aog), akuades, bufer tris-Boric-EDTA (TBE), etidium bromida, agarosa, $1 \mathrm{~kb}$ DNA ladder, kit isolasi DNA (InnuPrep plant DNA kit, Analytik Jena) dan kit PCR (GoTaq ${ }^{\circledR}$ Green Master Mix, Promega).

\subsection{Isolasi DNA (Kolondam, 2012).}

Isolasi DNA total daun pangi dilakukan dengan menggunakan prosedur sesuai manual InnuPrep plant DNA kit (Analytik Jena) yang telah dimodifikasi. Diambil daun pangi segar, dipotong jaringan daun dengan ukuran 5 × $5 \mathrm{~mm}$ atau berat $0.0048 \mathrm{~g}$, dimasukkan kedalam tabung mikro (eppendorf) kemudian digerus hingga jaringan daun hancur, ditambahkan larutan pelisisSLS $300 \mu \mathrm{L}$ dan proteinase $25 \mu \mathrm{L}$ kemudian diinkubasi selama 45 menit pada suhu $55^{\circ} \mathrm{C}$ menggunakan termoblok lalu disentrifugasi dengan kecepatan $12.000 \mathrm{rpm}$ selama 1 menit. Supernatan dipipet ke dalam tabung mikro baru dan dicampur dengan $200 \mu \mathrm{L}$ larutan pengikat SBS, kemudian disentrifugasi dengan kecepatan 12.000 rpm selama 1 menit.

Kolom miniprep ditempatkan pada tabung mikro, kemudian supernatannya diambil dan dimasukkan kedalam kolom miniprep lalu disentrifugasi dengan kecepatan $12.000 \mathrm{rpm}$ selama 1 menit. Filtrat dalam tabung dibuang dan kolom miniprep ditempatkan kembali ke tabung mikro, lalu dimasukan larutan pencuci W1 (HS) sebanyak $500 \mu \mathrm{L}$ kedalam kolom dan disentrifugasi dengan kecepatan $12.000 \mathrm{rpm}$ selama 1 menit. Filtrat dibuang dan kolom miniprep ditempatkan kembali pada posisi semula, kemudian dimasukkan larutan pencuci W2 (MS) sebanyak $700 \mu \mathrm{L}$ kedalam kolom dan disentrifugasi, langkah ini dilakukan sebanyak 2 kali ulangan. Kolom miniprepdipindahkan ke tabung mikro yang baru, kemudian DNA dielusikan dengan menambahkan larutan pengelusi $100 \mu \mathrm{L}$, didiamkan pada suhu ruang selama 1 menit dan disentrifugasi dengan kecepatan $10.000 \mathrm{rpm}$ selama 1 menit. DNA total yang diperoleh disimpan dalam suhu $-20^{\circ} \mathrm{C}$.

\subsection{Amplifikasi Gen matK dengan Polymerase Chain Reaction (PCR)}

Komposisi reaksi amplifikasi menggunakan PCR terdiri dari : primer forward gen matK yaitu matK-3F-R (5'-CGT ACA GTA CTT TTG TGT TTA CGA G3') dan primer reverse gen matK-IR-F (5'-ACC CAG TCC ATC TGG AAA TCT TGG TTC-3') (Stoeckle et al., 2011).DNA total daun pangi yang telah diisolasi 
sebanyak $2 \mu \mathrm{L}$ sebagai DNA templat, ditambahkan 1 $\mu \mathrm{L}$ primer forward, $1 \mu \mathrm{L}$ primer reverse, GoTaq ${ }^{\circledR}$ Green Master Mix (Promega) $5 \mu \mathrm{L}$ dan $16 \mu \mathrm{L} \mathrm{ddH}_{2} \mathrm{O}$. Reaksi PCR dilakukan dalam volume total $25 \mu \mathrm{L}$.

Proses PCR dimulai dari pra-denaturasi DNA templat pada suhu $95^{\circ} \mathrm{C}$ selama 2 menit, kemudian denaturasi DNA templat dilakukan pada suhu $95^{\circ} \mathrm{C}$ selama 30 detik, penempelan primer (annealing) dilakukan pada suhu $50^{\circ} \mathrm{C}$ selama 30 detik, polimerisasi DNAdilakukan pada suhu $72^{\circ} \mathrm{C}$ selama 50 detik dan polimerisasi DNA akhir pada suhu $72^{\circ} \mathrm{C}$ selama 1 menit. Siklus ini dilakukan sebanyak 35 kali (Stoeckle et al., 2011).

Pita DNA hasil PCR selanjutnya dielektroforesis menggunakan gel agarosa $1 \%$ dan divisualisasi menggunakan UV-Transiluminator. Produk PCR selanjutnya disekuensing di First Base Laboratories Sdn Bhd, Malaysia.

\subsection{Analisis Data}

Sekuensing DNA yang diperoleh dalam bentuk kromatogram disunting dengan menggunakan software Geneious 7.1.5 (Drummond et al., 2012). Bagian awal DNA dan akhir dihapus kurang lebih 30 bp. Sekuensing DNA yang dihasilkan dari primer reverse akan dilanjutkan dengan proses reverse dan complement yang kemudian digabungkan dengan hasil sekuensing primer forward menggunakan multiple sequence comparison by log-expectation (MUSCLE). Hasil suntingan sekuens matK pangi, selanjutnya dianalisis menggunakan Basic Local Alignment Search Tool (BLAST) untuk membandingkan urutan sekuens matK tumbuhan pangi dengan kerabat terdekat di GenBank (http://www.ncbi.nlm.nih.gov/) (Dereeper et al., 2008). Selanjutnya dilakukan analisis in-silico terhadap matk dari sepuluh kerabat terdekat pangi.

\section{Hasil dan Pembahasan}

\subsection{Isolasi DNA Total}

Hasil isolasi DNA daun pangi menunjukkan dua lapisan yaitu berwarna putih bening (DNA) dan warna sedikit hijau (klorofil). Hal ini menandakan bahwa DNA terisolasi Innuprep plant DNA kit dengan baik. DNA yang diperoleh disimpan ke dalam freezer, penyimpanan ini bertujuan untuk menghambat terjadinya denaturasi sebelum digunakan ke proses PCR (tahap replikasi DNA).

Hasil isolasi DNA tumbuhan pangi yang diperoleh akan dilanjutkan ke proses amplifikasi PCR menggunakan pemanasan. Dalam pemanasan ini DNA akan melewati 5 tahapan yaitu pradenaturasi DNA, denaturasi DNA, penempelan primer, polimerisasi DNA dan polimerisasi DNA akhir. Tahapan ini disebut dengan proses replikasi DNA secara enzimatik tanpa menggunakan organisme. Dengan teknik ini, DNA dapat dihasilkan dalam jumlah besar serta waktu relatif singkat dan memudahkan teknik lain yang menggunakan DNA seperti elektroforesis dan sekuensing. Hasil amplifikasi gen matK dengan PCR tumbuhan pangi yang dilakukan dalam proses elektroforesis dapat dilihat pada (Gambar 1). Berdasarkan ukuran DNA ladder, menunjukkan bahwa pita DNA pangium edule berada pada ukuran diantara 700 bp dan 800 bp yaitu 799 bp.

\subsection{Hasil sekuens DNA dan analisis asam amino}

Amplifikasi DNA menggunakan teknik PCR menghasilkan fragmen DNA sepanjang kurang dari 800 bp. Hasil sekuensing fragmen DNA yang menunjukkan panjang 720 bp yang tramplifikasi primer forward (Gambar 8) dan 780 bp (Gambar 9) untuk yang teramplifikasi primer reverse menunjukkan puncak-puncak dalam 4 warna yang berbeda sesuai dengan warna basa pirimidin dan basa purin tertentu. Hasil sekuensing yang baik ditunjukkan oleh grafik dengan puncak yang sangat tinggi dan terpisah satu sama lain. Sedangkan hasil sekuensing yang jelek ditunjukkan pada puncak landai atau tidak terpisah satu sama lain. Namun sekuensing fragmen DNA yang diperoleh cukup spesifik karena urutan basa yang divisualisasi berhasil terbaca semua.

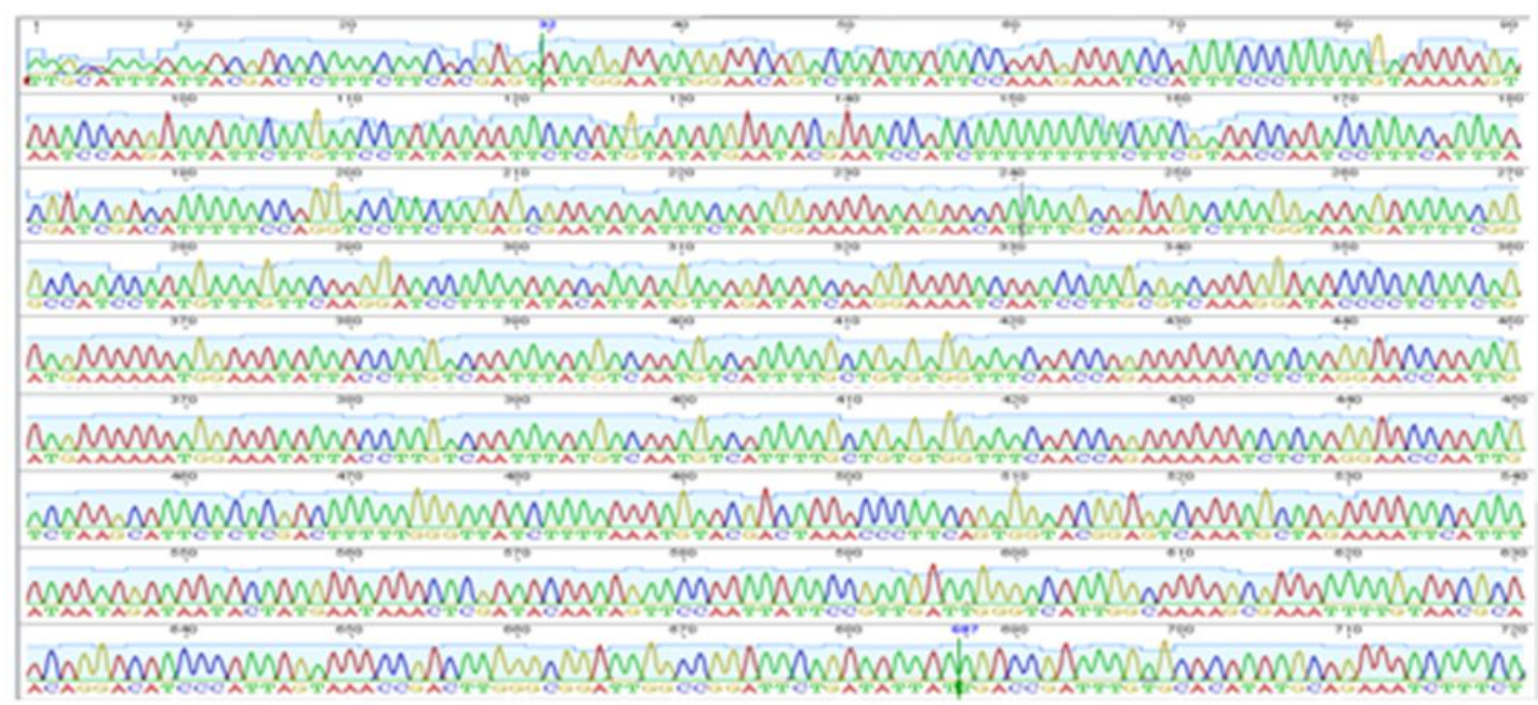

Gambar 2. Hasil sekuensing forward matK tumbuhan pangi. 


\section{irs

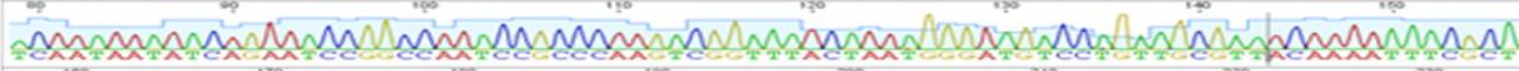

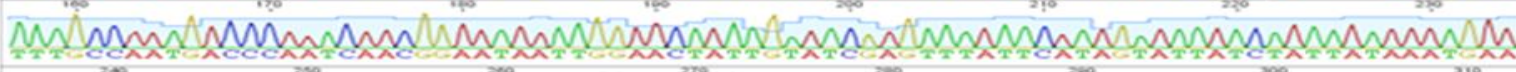

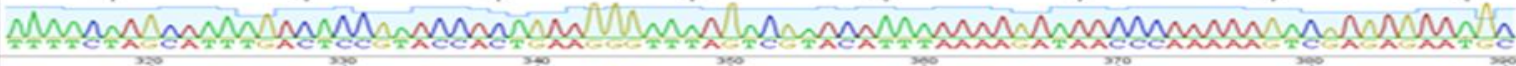

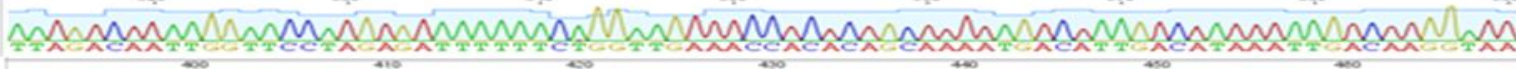

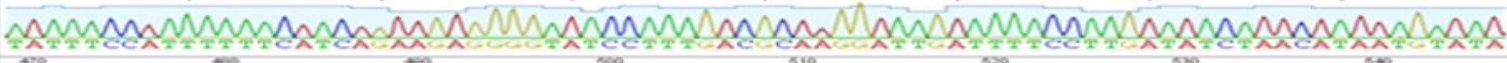 ANhmminnm

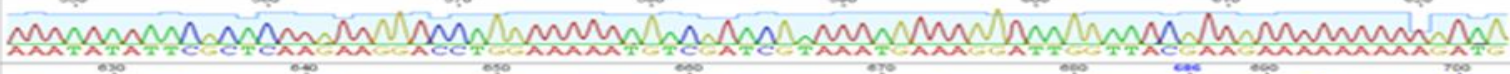

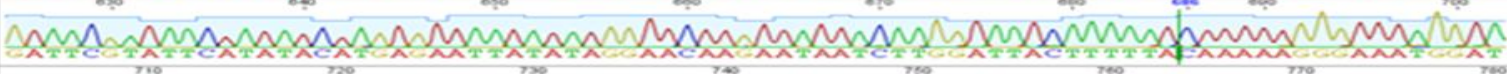

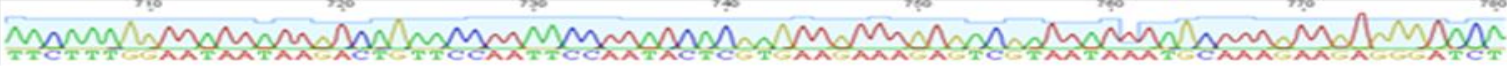

Gambar 3. Hasil sekuensing reverse matK tumbuhan pangi.

Barcode DNA berupa hasil penjajaran sekuens DNA dari primer forward dan primer reverse tumbuhan pangi (Gambar 4) menunjukkan kemiripan genetik yang lestari. Dengan demikian bahwa kedua primer tersebut teramplifikasi gen matK dalam teknik Polymerase Chain Reaction (PCR) dengan baik.

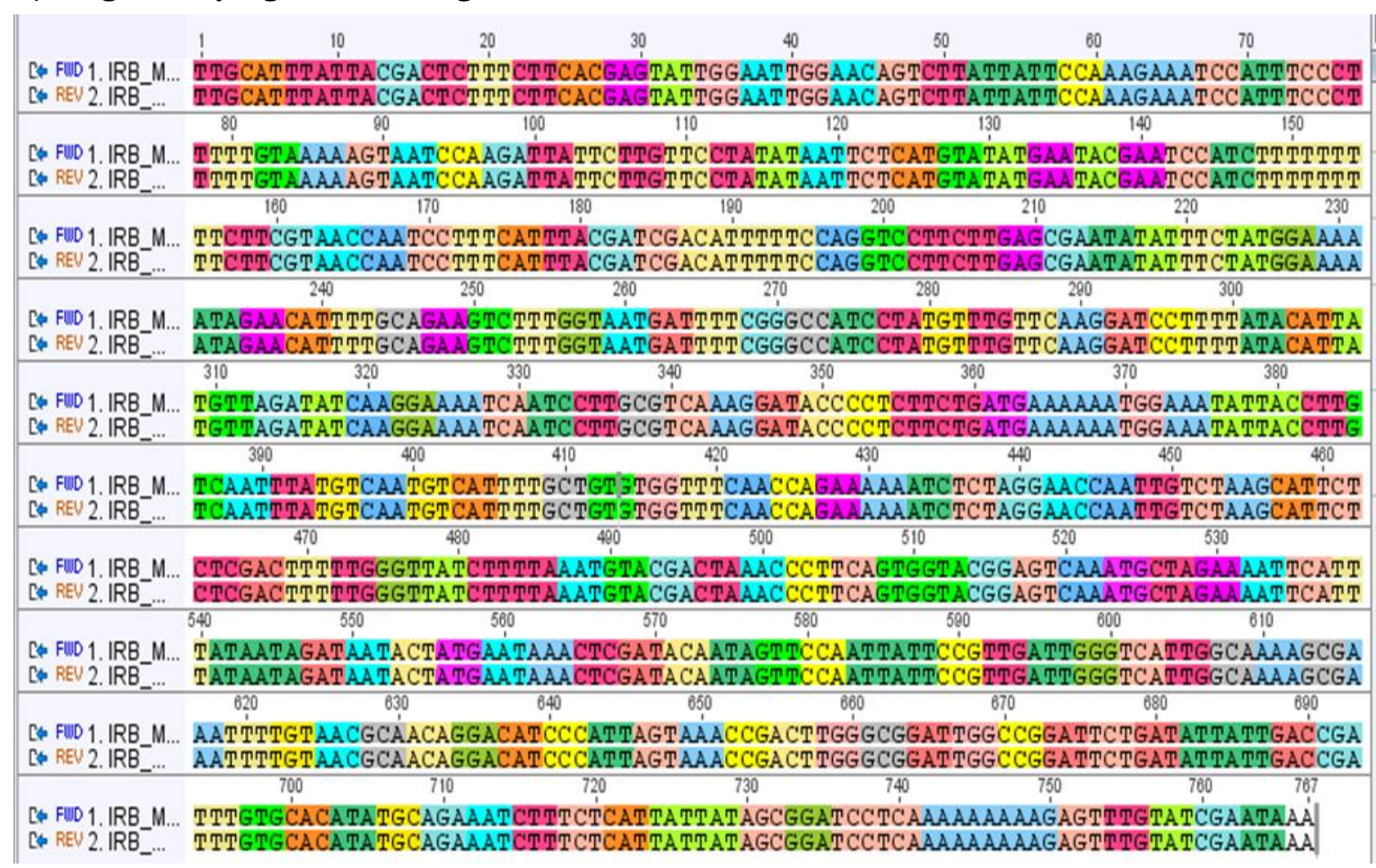

Gambar 4. Barcode DNA hasil penjajaran dari sekuens forward dan reverse matK tumbuhan pangi.

\subsection{Analisis in-silico MatK}

\subsubsection{Penjajaran MatK dengan BLAST}

Sebanyak sepuluh spesies tumbuhan dipilih untuk analisis asam amino. Tabel 1 menunjukkan nama-nama spesies tumbuhan yang telah dipilih berdasarkan tingkat kemiripan yang hampir mendekati dengan tumbuhan pangi. Spesies ini diunduh dalam program BLAST untuk keperluan analisis selanjutnya yaitu penjajaran urutan sekuens
DNA, analisis komposisi asam amino dan penentuan sifat fisika-kimia protein.

Penjajaran sekuens DNA dilakukan melalui situs NCBI (www ncbi.nlm.nih.gov) dan divisualisasikan dengan BLAST. Hasil penjajaran DNA Pangium edule dengan sepuluh spesies tumbuhan yang diambil dari GenBank menunjukan bahwa selain memiliki tingkat kesamaan pada jajaran asam amino, juga memiliki tingkat perbedaan yang dominan, tampak pada asam amino berwarna biru (Gambar 5). 
Tabel 1. Tumbuhan yang digunakan dalam analisis asam amino]

\begin{tabular}{|c|c|l|c|}
\hline No & Kode Akses & \multicolumn{1}{|c|}{ Organisme Sumber } & Tingkat Kemiripan \\
\hline 1. & ACY03316 & Pangium edule & $100 \%$ \\
\hline 2. & ABR22792 & Trichadenia zeylanica & $99 \%$ \\
\hline 3. & ABR22756 & Kiggelaria Africana & $98 \%$ \\
\hline 4. & ABR22748 & Guthriea capensis & $96 \%$ \\
\hline 5. & ABR22715 & Acharia tragodes & $92 \%$ \\
\hline 6. & ABR22741 & Erythrospermum phytolaccoides & $92 \%$ \\
\hline 7. & ABR22754 & Hydnocarpus sp. Chase 1301 & $90 \%$ \\
\hline 8. & ABR22727 & Carpotroche longifolia & $89 \%$ \\
\hline 9. & ACY03329 & Moultonianthus leembruggianus & $89 \%$ \\
\hline 10. & ABR22778 & Pimelodendron zoanthogyne & $88 \%$ \\
\hline
\end{tabular}

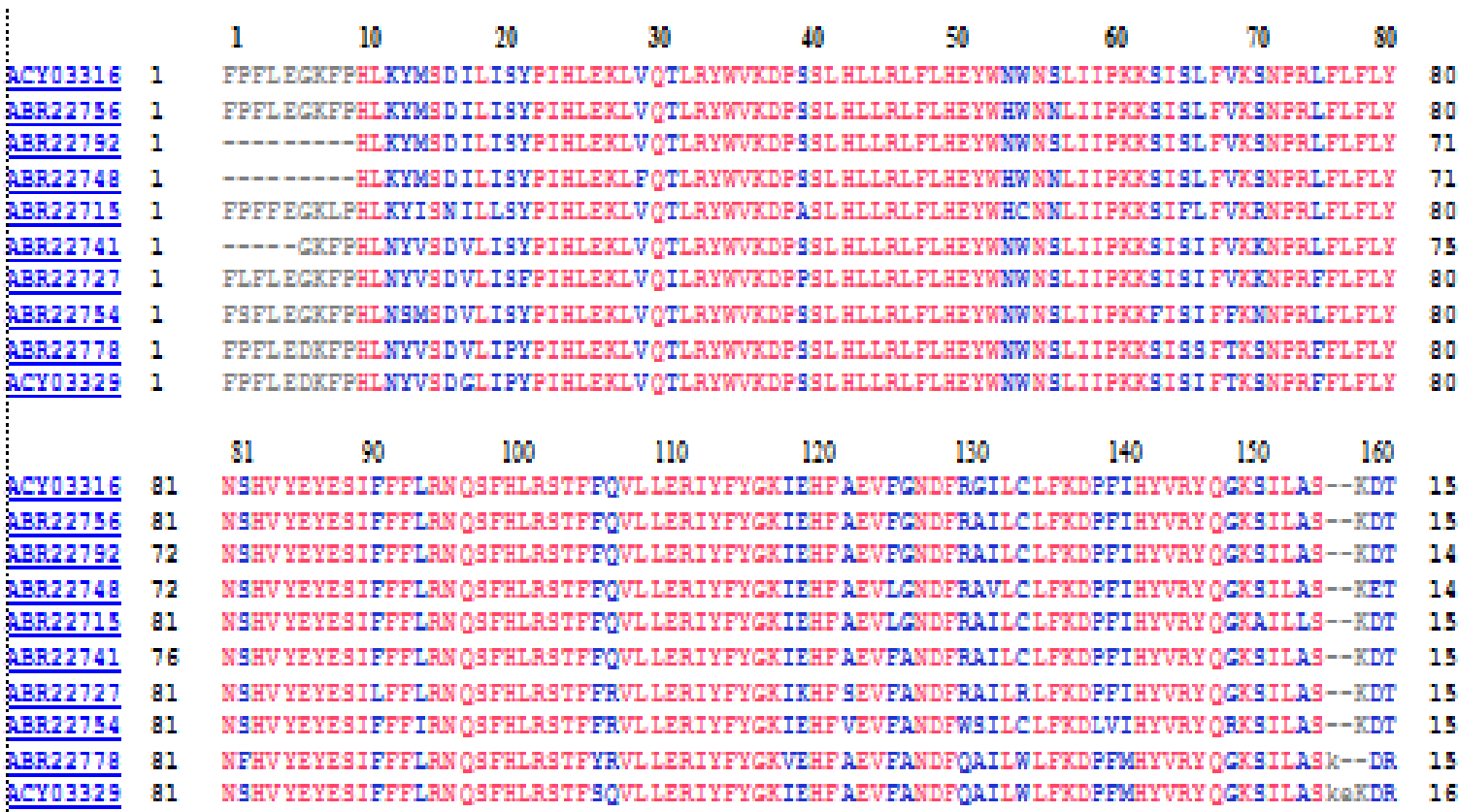

Gambar 5. Penjajaran urutan sekuens barcode DNA berdasarkan gen matK tumbuhan pangi (Pangium edule) dengan kerabat terdekat di GenBank

Hasil visualisasi sekuens DNA berdasarkan gen matk spesies lain, tingkat kemiripan Trichadenia zeylanical sangat tinggi dengan tumbuhan pangi (Tabel 1) yaitu 99\% dan diikuti spesies lainnya (Kiggelaria africanal, 98\%; Guthriea capensis, 96\%; Acharia tragodes, 92\%; Erythrospermum phytolaccoides, 92\%; Hydnocarpus sp. Chase 1301, 90\%; Carpotroche Iongifolia, 89\%; Moultonianthus leembruggianus, $89 \%$ dan Pimelodendron zoanthogyne, 88\%). Dengan hasil persentase tersebut dan penjajaran sekuens barcode DNA, gen matk dikatakan mampu membandingkan atau membedakan variasi antar spesies tumbuhan yang berkerabat dekat di GenBank.

\subsubsection{Analisis asam amino}

Analisis asam amino merupakan suatu identifikasi kadar asam-asam amino yang terkadung dalam suatu protein. Hasil analisis komposisi asam amino (Tabel 2), menunjukkan bahwa matk
Pangium edule dan kesembilan spesies lainnya lebih bersifat hidrofobik, karena memiliki residu asam amino non-polar cukup tinggi, hal ini ditunjukkan pada residu asam amino leusin (L). Asam amino yang semakin bersifat hidrofobik biasanya terdapat dibagian dalam protein yang berinteraksi dengan lipida.

Tabel 3 menunjukkan sifat fisika-kimia protein dari spesies Pangium edule dengan kerabat terdekat di GenBank. Berdasarkan data bobot molekul (BM) dari kesepuluh spesies tersebut berkisar antara 43.237,5-44.986,5 Da. Sedangkan koefisien ekstingsinya (KE) molar bervariasi antara $74175-63175 \mathrm{M}^{-1} \mathrm{~cm}^{-1}$. Koefisien ekstingsi ACY03316, ABR22778 dan ACY03329 lebih tinggi diantara protein yang lain. Nilai koefisien ekstingsi dapat digunakan dalam analisis kuantitatif interaksi antar protein dengan protein, bahkan protein dengan ligan. 
Tabel 2. Analisis komposisi asam amino Pangium edule dengan kerabat terdekat di GenBank menggunakan protparam (dalam \% mol).

\begin{tabular}{|c|c|c|c|c|c|c|c|c|c|c|}
\hline \multirow[b]{2}{*}{$\begin{array}{l}\text { Residu } \\
\text { asam } \\
\text { amino }\end{array}$} & \multicolumn{10}{|c|}{ Protein Pangium edule dengan spesies lain } \\
\hline & 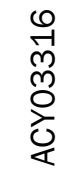 & 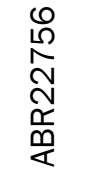 & \begin{tabular}{l} 
N \\
$\stackrel{N}{N}$ \\
\multirow{N}{*}{} \\
$\frac{1}{4}$
\end{tabular} & 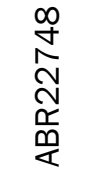 & 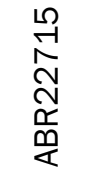 & $\begin{array}{l}\underset{+}{N} \\
\underset{N}{N} \\
\underset{\sim}{\sim} \\
\frac{1}{\alpha}\end{array}$ & 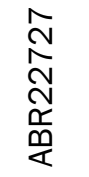 & 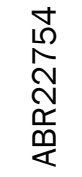 & 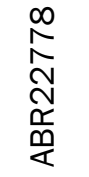 & 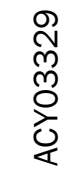 \\
\hline Met (M) & 1.1 & 1.1 & 1.1 & 1.1 & 0.8 & 0.8 & 0.8 & 1.3 & 1.1 & 1.1 \\
\hline Cys (C) & 1.9 & 1.9 & 1.9 & 1.9 & 2.1 & 1.9 & 1.6 & 1.9 & 1.3 & 1.3 \\
\hline $\operatorname{Trp}(\mathrm{W})$ & 2.1 & 1.9 & 1.9 & 1.9 & 1.6 & 1.6 & 1.6 & 1.9 & 1.9 & 1.9 \\
\hline $\mathrm{Gln}(\mathrm{Q})$ & 2.4 & 2.4 & 2.5 & 2.5 & 2.4 & 2.4 & 1.9 & 1.9 & 2.7 & 2.7 \\
\hline Ala (A) & 2.7 & 2.9 & 3.0 & 3.0 & 2.9 & 3.0 & 2.7 & 2.4 & 2.7 & 2.7 \\
\hline Gly (G) & 2.9 & 2.7 & 2.5 & 2.5 & 2.9 & 2.2 & 2.1 & 2.1 & 2.1 & 2.1 \\
\hline $\operatorname{Thr}(\mathrm{T})$ & 2.9 & 3.2 & 2.7 & 3.0 & 2.9 & 2.7 & 2.7 & 2.4 & 2.4 & 2.7 \\
\hline Asp (D) & 4.0 & 3.8 & 4.1 & 3.6 & 3.2 & 4.1 & 4.0 & 3.8 & 4.0 & 4.0 \\
\hline His $(\mathrm{H})$ & 4.0 & 4.3 & 4.1 & 4.4 & 4.3 & 3.8 & 3.8 & 3.8 & 3.7 & 3.7 \\
\hline Pro $(\mathrm{P})$ & 4.3 & 4.0 & 3.8 & 3.6 & 4.0 & 3.8 & 4.3 & 3.5 & 4.3 & 4.2 \\
\hline Glu (E) & 4.3 & 4.3 & 4.1 & 4.4 & 4.3 & 4.3 & 4.0 & 4.6 & 4.5 & 4.8 \\
\hline Asn (N) & 4.3 & 4.6 & 4.4 & 4.7 & 4.8 & 4.3 & 4.6 & 5.1 & 4.8 & 4.8 \\
\hline Val (V) & 4.8 & 4.8 & 4.9 & 4.9 & 4.8 & 5.4 & 5.4 & 5.4 & 5.1 & 5.0 \\
\hline $\operatorname{Tyr}(\mathrm{Y})$ & 5.4 & 5.4 & 5.5 & 5.5 & 5.6 & 5.7 & 5.4 & 5.1 & 6.1 & 5.6 \\
\hline $\operatorname{Arg}(\mathrm{R})$ & 5.9 & 5.6 & 6.3 & 5.8 & 5.9 & 6.0 & 6.7 & 6.4 & 6.4 & 6.4 \\
\hline Lys (K) & 7.5 & 7.5 & 7.4 & 7.4 & 7.7 & 8.2 & 8.3 & 7.2 & 7.5 & 8.0 \\
\hline Phe (F) & 7.8 & 8.0 & 7.1 & 7.4 & 8.0 & 7.3 & 8.0 & 8.6 & 8.3 & 7.4 \\
\hline Ile (I) & 8.0 & 7.5 & 8.2 & 8.0 & 8.5 & 8.7 & 8.6 & 8.8 & 8.5 & 8.5 \\
\hline Ser (S) & 9.9 & 10.2 & 10.2 & 10.2 & 9.1 & 10.1 & 9.9 & 10.5 & 10.1 & 10.3 \\
\hline Leu (L) & 13.7 & 13.9 & 14.0 & 14.3 & 14.1 & 13.6 & 13.7 & 13.4 & 12.5 & 13.0 \\
\hline
\end{tabular}

Tabel 3. Sifat fisika-kimia protein Pangium edule dengan kerabat terdekat di GenBank.

\begin{tabular}{|c|c|c|c|c|c|c|c|}
\hline No & Protein & Ukuran & BM (Da) & KE & pl & II & GRAVY \\
\hline 1 & ACY03316 & 373 & 44315.8 & 74175 & 9.55 & 35.25 & -0.064 \\
\hline 2 & ABR22756 & 373 & 44248.6 & 68675 & 9.55 & 36.75 & -0.059 \\
\hline 3 & ABR22792 & 364 & 43248.6 & 68675 & 9.60 & 35.51 & -0.061 \\
\hline 4 & ABR22748 & 364 & 43237.5 & 68675 & 9.56 & 33.99 & -0.037 \\
\hline 5 & ABR22715 & 375 & 44539.3 & 64790 & 9.65 & 34.34 & -0.003 \\
\hline 6 & ABR22741 & 368 & 43716.2 & 64665 & 9.59 & 34.87 & -0.041 \\
\hline 7 & ABR22727 & 373 & 44453.2 & 63175 & 9.80 & 34.16 & -0.052 \\
\hline 8 & ABR22754 & 373 & 44549.2 & 67185 & 9.61 & 35.64 & 0.014 \\
\hline 9 & ABR22778 & 375 & 44954.4 & 73020 & 9.62 & 37.43 & -0.124 \\
\hline 10 & ACY03329 & 377 & 44986.5 & 70040 & 9.65 & 39.62 & -0.152 \\
\hline
\end{tabular}

Data isoelektrik (pl) merupakan $\mathrm{pH}$ dari suatu protein yang memiliki nilai lebih dari 7 , hal ini menunjukkan bahwa kesepuluh spesies tersebut memiliki protein bersifat basa.Program protparam juga menampilkan nilai indeks ketidakstabilan (II) dari kesepuluh protein yaitu 33.99-39.62. Indeks ketidakstabilan sangat mempengaruhi konsentrasi suatu larutan protein. Berdasarkan nilai GRAVY, kesepuluh protein yang terdata membentuk ion negatif yaitu berkisar antara -0.152 sampai -0.003, hal ini menunjukkan bahwa protein berada dalam suasana basa yang berinteraksi sangat baik dengan air. 


\section{Kesimpulan}

Berdasarkan hasil penelitian dapat disimpulkan bahwa:

1. Gen matK pangi (Pangium edule) berhasil diamplifikasi dengan PCR. Hasil sekuensing fragmen DNA yang menunjukkan panjang 720 bp yang teramplifikasi oleh primer forward dan 780 bp untuk yang teramplifikasi oleh primer reverse.

2. Hasil analisis BLAST menunjukkan tingkat kemiripan tumbuhan pangi ( $P$. edule) sangat tinggi dengan Trichadenia zeylanical, yaitu 99\%. Analisis komposisi asam amino menunjukkan bahwa matK $P$. edule dan kesembilan spesies tumbuhan kerabat terdekatnya bersifat hidrofobik.

\section{Daftar Pustaka}

Basuni, S. 1986. Lampu Kuning bagi Status Pohon Pangi. Media Konversi 1: 17 - 19.

Burkill, I.H. 1935. A Dictionary Of The Economic Product Of The Malay Peninsula. Goverments Of The Straits Settlements. London. Page 45.

Darwis, D. 2000. Teknik Dasar Laboratorium Dalam Penelitian Senyawa Bahan Alam Hayati, Workshop Pengembangan Sumber Daya Manusia Dalam Bidang Kimia Organik Bahan Alam Hayati. FMIPA Universitas Andalas, Padang.

Dereeper, A., V. Guignon, G. Blanc, S. Audic, S. Buffet, Chevenet, J.F. Dufayard, S. Guindon, V. Lefort, M. Lescot, J.M. Claverie, and O. Gascuel. 2008. Phylogeny. fr: robust phylogenetic analysis for the non-specialist. Nucleic Acids Research. 1: 36.

Drummond A.J., B. Ashton, S. Buxton, M. Cheung, A. Cooper, C. Duran, M. Field, J. Heled, M. Kearse, S. Markowitz, R. Moir, S. Stones-Havas, S. Sturrock, T. Thierer, and A. Wilson. 2012. Geneious v5.6. Biomatters, New Zealand.

Fessenden,R.J., and J.S. Fessenden. 1986.Organic Chemistry. Third Edition, University Of Montana, , Wadsworth, Inc, Belmont, Califfornia 94002. Massachuset, USA.

Handoyo, D., dan A. Rudiretna. Prinsip Umum dan Pelaksanaan Polymerase Chain Reaction (PCR). Unitas. 9:17-29.

Hebert, P.D.N., N.A. Cywinska, S.L. Ball, and J.R. Waard (2003) Biological identifications through DNA barcodes. Proc. Roy. Soc. B-Biol. Sci. 270: 313-321.

Heriyanto, N.M., danE. Subiandono. 2008. Ekologi pohon kluwak/pakem (Pangium edule Reinw.) di Taman Nasional Meru Betiri Jawa Timur. Buletin Plasma Nutfah 14: 33-42.
Hollingsworth, P.M., S.W. Graham, dan D.P. Little. 2011. Choosing and using a plant DNA barcode. Plo. Sone. 6:e19254.

Kolondam, B.J. 2012. Barcode DNA rbcL dan matK Aglaonema (Aglaonema sp.), Anthurium Gelombang Cinta (Anthurium plowmanii) dan Anggrek Payus Limondok (Phaius tancarvilleae) [tesis]. Program Pascasarjana UNSRAT, Manado.

Kress, W.J., K.J. Wurdack, E.A. Zimmer, L.A.Weigt, and D.H. Janzen. 2005. Use of DNA barcodes to Identify Flowering Plants. P. Natl. Acad. Sci. USA. 102: 8369-8374.

Lawodi, E.N., T.E. Tallei, F.R. Mantiri, dan B.J. Kolondam. 2013. Variasi Genetik Tanaman Tomat dari Beberapa Tempat Di Sulawesi Utara Berdasarkan Gen matK. Jurnal IImiah Farmasi. 2: 144-121.

Lehninger, A.L. 1982. Dasar-dasar Biokimia Jilid 1. Erlangga,Jakarta.

Newton, C.R., and A. Graham. 1994. Polymerase Chain Reacton (PCR). UK: Bios Scientific Publisher.

Partomihardjo, T., dan Rugayah. 1989. Pangi (Pangium edule Reinw) dan Potensinya yang Mulai dilupakan. Media Konservasi. 2:45-50.

Rianta, P. 2001. Mengenal Metode Elektroforesis. Oseana. 24: 25-31.

Rimbawanto, A., B. Leksono, dan Widyatmoko. 2012. Bioteknologi Hutan untuk Produksi dan Konservasi Sumber Daya Hutan. Prosiding Balai Besar Penelitian Bioteknologi dan Pemuliaan Tanaman Hutan; Yogyakarta, 9 Oktober 2012. Seminar Nasional Bioteknologi Hutan. HIm 1120.

Soltis, E.D., S.P. Soltis, and J.J. Doyle. 1992. Choosing an Approach and an Appropriate Gene for Phylogenetic Analysis. Kluwer Academi Publisher. Netherlands. 2:3-11.

Stoeckle, Y.M., C.C. Gamble, R. Kirpekar, G. Young, S. Ahmed, dan D.P. Little. 2011. Commercial teas highlight plant DNA barcode identification successes and obstacles. Sci Rep. 1: 42.

Sudarmono. 2006. Pendekatan Konservasi Tumbuhan dengan Teknik Molekuler Elektroforesis. Inovasi. 7: 50-56.

Witarto, A.B. 2001. Protein Engineering: Perannya dalam Bioindustri dan Prospeknya di Indonesia. Bioteknologi Indonesia; 1-14 Februari 2001. Seminar on-Air Bioteknologi untuk Indonesia. HIm 2-5.

Yuningsih, R. Damayanti, dan L. Udarno. 2004.Efek Toksiko-Patologik beberapa Tanaman Beracun pada Mencit dalam Upaya Mencari Zat Pengganti Racun Strychnine untuk Pemberantasan Penyakit Rabies pada Anjing. Seminar Nasional Teknik Peternakan. 96: 767 - 775. 